\title{
Bireysel Emeklilik Fon Tercihlerini Etkileyen Unsurlar Üzerine Bir Calıșma
}

Selim AREN ${ }^{\star}$ - Sibel Dinç AYDEMiR ${ }^{\star \star}$ - Arzu Rahime UÇAR ${ }^{\star \star \star}$

Makale Gönderim Tarihi: 24.10.2014

Makale Kabul Tarihi: 08.01.2015

\section{ÖZ}

Bu çalıșmanın amacı, bireysel emeklilik fon tercihlerini etkileyen değișkenleri ve finansal danıșmanlara tavsiyede bulunurken rehberlik edecek unsurları belirlemektir. Bunun için kolayda örnekleme yöntemiyle bireysel emeklilik sistemine katılmıș bireylerden olușan örneklem kullanılmıștır. Diskriminant analiziyle yaș, eğitim ve risk alma davranıșının fon tercihinde görece yüksek öneme sahip olduğu tespit edilmiș, bireylerin seçeceği fon türünü tahminleyen bir fonksiyon hesaplanmıștır. Ayrıca, risk algısının değișip değișmediği ANOVA ile araștırılmıș, fon türüne göre risk algısının bazı boyutlarında değișiklik olduğu tespit edilmiștir.

Anahtar Kelimeler: Bireysel emeklilik fon tercihi, duygusal zeka, finansal okuryazarlık, risk algısı ve risk alma.

\section{A Study on The Factors Influencing Individual Retirement Fund Choices}

\section{ABSTRACT}

This study aims to identify factors having impact on retirement fund choices and to establish guiding elements for financial advisors. For this purpose, the conveniently chosen sample was

Prof. Dr. , Yıldız Teknik Üniversitesi

** Uzman, Gebze Yüksek Teknoloji Enstitüsü, saydemir@gyte.edu.tr.

*** Yüksek Lisans Öğrencisi, Gebze Yüksek Teknoloji Enstitüsü 
employed. Discriminant analysis shows that age, education and risk taking behavior are relatively important to fund choice and presents a function predicting which fund individuals could select according to these mentioned factors. Additionally, ANOVA shows that certain aspects of risk perception vary according to fund type.

Keywords: Individual retirement fund choice, emotional intelligence, financial literacy, risk perception, risk taking.

\section{Gíriș}

Emeklilik sistemleri her ülkede olduğu gibi ülkemizde de önem arz etmektedir. Kișilerin faal çalıșma hayatları bittiğinde, var olan standartlarını devam ettirmeleri zorunlu yapılan sosyal güvenlik sistemi ile mümkün olamamaktadır. Bu sebeple kișiler çalıșma hayatları boyunca çeșitli birikim ve yatırım yapma isteğindedirler. Bireysel emeklilik sistemi bu ihtiyaca cevap veren çok faydalı bir uygulamadır. Özellikle ülkemizde devlet katkısının olması sebebiyle her geçen gün daha da cazip hale gelmekte ve yeni katılımcılar ile büyümektedir. Ancak bilinçsizce yapılan fon tercihleri ve/veya uygun olmayan finansal danıșman tavsiyeleri bireyleri mutsuz edebileceği gibi sisteme de zarar verebilecektir. Doğru fon tercihi, kișilerin ulașmak istedikleri getiri hedefi ile ilgili olduğu gibi sahip oldukları çeșitli özellikleri ile de ilișkilidir. Danıșman tavsiyesi ise kișiye özel olacağı için, ilk önce danıșman tarafından karșısındaki kișinin özellikleri ve beklentileri anlașılmalı ve buna uygun tavsiyelerde bulunulmalıdır.

Bu çerçevede bu çalıșmadaki amacımız bireysel emeklilik sistemindeki kișilerin demografik özellikleri, risk alma davranıșları ve duygusal zekâları ile fon tercihlerini açıklamaktır. Bunun için ilk önce diskriminant analizi ile fon tercihinde etkili olan değișkenler tespit edilmiștir. Elde edilen fonksiyon denklemi ile de sisteme girmeyi düșünen kișilerin ilgili özellikleri ölçülerek uygun fon tavsiye edilmesinin yolu açılmıștır. Ayrıca risk alma davranıșı ile ilișkili ancak farklı bir kavram olan risk algısı da çeșitli yönleri ile ölçülmüș ve fon tercihlerine göre risk algısındaki farklılıklar tespit edilmiștir. 
Çalışmamızda kişilerin fon tercihinde eğitim, yaş ve risk alma davranışlarının önemli etkisinin olduğu buna karşılık duygusal zekâ ve finansal okuryazarlık seviyesinin etkisinin oldukça düşük düzeyde kaldığ 1 tespit edilmiştir. Ayrıca bireysel emeklilikte farklı fon tercihlerindeki kişilerin risk algılarına ilişkin de farklılıklar görülmüştür. Yatırım isteği, yatırıma ilişkin endişeleri ve kayba ilişkin tutumları fon tercihine göre farklılık göstermektedir.

\section{Literatür Taraması}

Bireylerin yatırım tercihlerine odaklanmak ve finansal karar verme mekanizmalarını anlayabilmek makro anlamda yatırımların ekonomik büyümenin tetikleyici olması, mikro anlamda finansal aracı kurulușların bireylerin farklılıklarını gözeten ürünler sunabilmesi ya da finansal danıșmanların bireylere özellikleriyle örtüșen tavsiyeler verebilmesi bakımından önemlidir. Bireylerin finansal karar verme mekanizmasını anlamak üzerine demografik faktörler ve risk alma lehine bir odaklanma mevcut olup araștırmacılar psikolojik unsurlar gibi bireysel farklılık yaratabilecek diğer faktörlerin de önemli olduğuna vurgu yapmaktadır.

\subsection{Duygusal Zekâ}

Kișilerin yașadıkları olayları yorumlamaları, çevrelerindeki uyaranlar ile bu uyaranların iç dünyalarında olușturduğu duyguların etkileșimi sonucu gerçekleșir. Bireyin herhangi bir konu hakkındaki davranıșlarını açıklayabilmek için duygularının anlașılması gerekmektedir. Çünkü duygular, düșünceleri; düșünceler ise bireyin davranıșlarını olușturmaktadır.

Karșılaștıkları durumlar karșısında bireylerin takındıkları tutumlar, yaș, cinsiyet, eğitim, yetiștirilme șartlarının yanı sıra zeka seviyesi ile ilișkilendirilmiștir. Çalıșmalarda zeka, rasyonel ve duygusal olmak üzere iki bașlık alında incelenmiștir. Kamalian ve diğ. (2011) insanın düșünen ve hissedenolmak üzere iki tür zekaya sahip olduğunu söylemiștir. Rasyonel zeka kișinin düșünme yetisi olmakla birlikte anlama kapasitesi olarak da yorumlanmıștır. Duygusal zeka ise bireyin duygularını iyi okuyabilmesi ve duyguları üzerinde hakim olabilme yeteneği olarak tanımlanmıștır. Duy- 
gusal zekâ kavramlaștırılmadan önce mantık ve duygunun çatıșma içerisinde olduğuna dair bir yargı bulunmaktaydı. Yapılan yeni araștırmalar duygusal ve bilișsel sistemlerin bilinenden daha entegre olduğunu ortaya koymuștur (Ergin ve Özgürol, 2011 1). Duygusal zekâ kavramı, bilișsel zeka seviyeleri eșit olsa da bireylerin neden farklı tutumlar ve bașarılar sergilediğini anlamamız noktasında bize açıklayıcı bir bakıș açısı sunmaktadır.

Yip ve Côté (2012) ise duygusal zekâyı, bireylere duygularını muhakeme etme, duyguları ve duygusal bilgiyi kullanabilme olanağı sağlayan bir yetenekler bütünü olarak tanımlar. Duygusal zeka modelleri; yetenek modeli, kișilik modeli ve karma model șeklinde adlandırılan üç bakıș açısı üzerinde geliștirilmiștir. Salovey-Mayer, Bar-On ve Goleman'ın geliștirdiği duygusal zekâ modelleri aslında birbiriyle çelișmeyip birbirini tamamlar niteliktedirler (Gündüz, 2013).

Salovey ve Mayer (1990) yetenek modelinde duygusal zekayı kișinin kendisinin ve bașkalarının hislerini ve duygularını ayırt edebilme için gözlemleme ve elde ettiği bilgileri düșünceleri ile davranıșları için rehber olarak kullanma yeteneği olarak tanımlamıșlardır.

Yetenek modeli olarak tanımlanan modelde Salovey ve Mayer (1990) düșünme sürecinden kendinin ve bașkalarının duygularını anlama; kendinde ve bașkalarında varolan duyguları düzenleme ve duyguları kullanma olmak üzere 3 farklı boyuttan bahseder. Düșünme sürecinin duyguları anlama olarak belirtilen ilk boyutunda, kișinin sözlü ve sözsüz iletișimdeki farkındalığının önemi değerlendirilir. Beden dilini okuma ve empati yeteneği de bireyin karșısındakinin duygularını analizinde önemli olduğundan bu boyutun içeriği olarak düșünülür. Duygunun düzenlemesi boyutu ise bireyin kendinde ve bașkalarındaki düșüncelerin anahtarı olan duyguları yönlendirebilmesi ve duyguları doğru bir șekilde adlandırması olarak belirtilir. Kișinin, kendisindeki ve iletișimde bulunduğu bireylerdeki duyguları doğru adlandırabilmesi, düșüncelerinde daha doğru bir analize ulașabilmesi ve gerekli durumlarda bu duyguları yönlendirebilmesi bu boyutun içeriğidir. Üçüncü boyut olarak incelenen duygunun kullanımın ise kișinin düșünce, 
dikkat ve motivasyonunu belirlemiș olduğu hedefine yönlendirmesi boyutu olarak belirtilir. Çalıșma, bu sürecin herkes için ortak olduğunu ancak bireylerin anlama kapasiteleri ve duygu ifade yeteneklerine göre farklılık gösterebileceğini belirtir. Olușabilecek bu durumlarda bireylerin anlama kapasiteleri ve duygu ifadelerindeki farklılıkların önemi olduğunu belirten araștırma, tüm bunların yanı sıra duygusal zekânın öğrenilebilir bir yetenek olduğunu belirtir.

Salovey ve Mayer (1990) yetenek modelinde duygusal zekânın ölçülebileceğini ve duygularını tanımlayabilen bireylerin problemleri çözmede diğer bireylerden daha bașarılı olabileceğini ortaya koymușlardır. Ayrıca Sosic ve Megerian (1999) duygusal zekâları yüksek olan kișilerin duygularını akıl yürütmeyi, yaratıcı düșünmeyi ve karar vermeyi kolaylaștırmak için kullanabileceklerini öne sürmüștür.

Çalıșmada kullanılan duygusal zeka ölçümünde, Schutte ve diğ. (1998) 'in geliștirmiș oldukları ölçek kullanılmıșıı. Bu ölçek, duygusal zeka kavramsal yetenek modelinin (Salovey ve Mayer, 1990) yazarlarca geçerliliği kanıtlanmıș ve her üç boyutuna ilișkin maddelerini 33 madde ve tek boyuta indirgeyen bir ölçüm aracıdir.

Literatürde duygusal zekanın eğitim (Humphrey ve diğ., 2007; Yeșilyaprak, 2001), akademik bașarı (Kavcar, 20111), yașamsal tatmin (Law vd., 2008), iș performansı ve bașarısı (Law vd., 2008; Doğan ve Demiral, 2007), çalıșan performansı (Jorfi vd., 2010), iș çıktısı (Rosete ve Ciarrochi, 2005), liderlik (Acar, 2002; Rosete ve Ciarrochi, 2005; Batool, 2013), karar verme (Köksal ve Gazioğlu, 2007; Kidwell vd., 2008) ile ilișkilendirildiği görülmektedir. Duygusal zekanın finansal çerçeveye oturtulduğu bazı araștırmalar (Ezadinea ve diğ, 2011 ; Swanson ve Braidfoot, 2013; Ameriks ve diğ., 2009) da olmasına karșın yatırımcıların finansal kararları üzerinde duygusal zekanın etkisini konu alan çok fazla sayıda çalıșma yoktur. Çalıșmanın, finansal karar vermeye yönelik anlayıșı ilerletmesi noktasında literature katkısının olması beklenmektedir.

Sjöberg ve Engelberg (2009) duygusal zekası yüksek olan insanların paraya daha az önem atfettiklerini belirtmiștir. Aynı za- 
manda duygusal zekası yüksek insanların bașkalarına karșı empati geliștirebilip, onların inanç ve değerlerini anlayabildiklerini ve tüm bu yeteneklerin finansal danıșmanlıkta oldukça önemli olduğunu belirtmiștir.

Diğer bir araștırmada ise duygusal zekası yüksek olan yatırımcıların, iyi performansla sonuçlanan yatırım davranıșları sergiledikleri bulunmuștur (Ameriks ve diğ., 2009). Bir diğer araștırmada, yüksek duygusal zekâya sahip insanların kendilerinin ve diğerlerinin duygularını anlama kapasitesine sahip olmaları sebebiyle duyguları analiz edip yönetebilecekleri belirtilmiș, dolayısıyla bu insanların, girișimciliğe yönelimlerinin de yüksek olduğu gösterilmiștir. Aynı çalıșmanın bir diğer çıkarımı da duygusal zekası yüksek olan bireylerin fırsatları doğru tanıyan, aktiviteleri özgün bir șekilde yapan ve girișimsel risk alımında yüksek bir beceriye sahip insanlar olduklarıdır (Kamalian ve diğ., 2011).

Duygusal zekâsı yüksek olan bireyler, kendilerini tanıyan ve ihtiyaçlarını bilen, güçlü ve zayıf yanlarının farkında olan, duygularını kontrol etmeyi bașarabilen ve etkili ilișkiler kurabilen kișilerdir. Ve bu bireyler çalıșma yașamında duygusal zekâsı düșük olanlara göre daha bașarılıdırlar (Doğan ve Demiral, 2007).

Bir çalıșmada yönetici ve çalıșanların, iș çevrelerinde olușan dinamik değișikliklerle bașa çıkabilmeleri adına, duygusal zekanın önemli bir role sahip olduğu ayrıca, düșük duygusal zekaya sahip olmalarının ișlerindeki performans seviyelerine etkisi olduğu belirlenmiștir (Jorfi ve diğ., 2010). Bir diğer çalıșmada da, duygusal zekânın yüksek olmasının bireylerin iș hayatlarındaki bașarıları üzerinde olumlu etkiye sahip olduğu belirtilmiștir (Doğan ve Demiral, 2007). Howard (2012), çalıșmasında șirket yöneticilerini incelemiștir. Buna göre, șirket yöneticilerinin artan duygusal zekalarının karar alma așamasındaki sistematik hata riskini azaltabileceğini doğrulamıșlardır.

Kidwell ve diğ. (2008) duygusal yeteneklerin tüketicilerin performansları hakkında bilișsel yeteneklerden daha fazla bilgi verdiğini ortaya koymuștur: Yüksek duygusal zekâya sahip tüketicilerin, düșük duygusal zekâya sahip tüketicilerden daha iyi tercihler yaptığı bulunmuștur. Ayrıca yüksek duygusal zekâya sahip 
tüketiciler cezbedici marka bilgilerine karșı direnç gösterip, daha az bilindiği halde daha iyi özelliklere sahip ürünleri seçmektedirler Yip ve Côté (2012), duyguları anlama yeteneği yüksek olan bireylerin belirli duygulara sebep olan olayları daha doğru bir șekilde tanımlayabildiklerini, daha düșük duyguları anlama yeteneğine sahip bireylerin ise yanlıș sebepler tanımlamaya daha meyilli olduklarını göstermiștir.

Bir diğer çalıșmada duygusal zekânın geliștirilmesinin karar verme sürecini olumlu etkilediği bulgusu elde edilmiștir (Humphrey ve diğ., 2007). Duyguların rasyonel düșünme sürecinden ayrılamadığını hatta duyguların rasyonel düșünme sürecinin merkezinde olması ve bireyin duygusal zekasının geliștirilmesi ile karar vermesinin kolaylașmasının doğru orantılı olduğu belirtilmiștir.

Yatırımcıların tercihleri üzerinde duygusal zekanın nasıl bir yansıması olduğunun anlașılmasına ıșı tutan Ameriks ve diğ. (2009) ise duygusal zekası yüksek olan yatırımcıların, iyi performansla sonuçlanan yatıım davranıșları sergilemekte olduklarını göstermiștir. Yatırım planlamasına dair bir bașka araștırma da sertifikalı finansal planlamacılar üzerine yapılmıștır. Bu çalıșma sonucunda, katılımcıların \% 83'ünden fazlasında duygusal zekâ hakkında bilgi edinmenin ișlerindeki finansal planlamalarda faydalı olduğu görülmüștür (Swanson ve Braidfoot, 2013).

Ayrıca, duygusal zekanın, hissedarların porfföy performanslarındaki artıșta etkisi olduğu ortaya çıkmıșıı (Ezadinea ve diğ., 2011 1). Genel olarak duygusal zekâsı yüksek olan yatırımcılar sıklıkla daha az hisse senedi alırlar, daha az finansal ișlem yaparlar ve daha çok indeks fonları kullanırlar. Bu yatırımcılar daha dengeli bir yatıım yaklașımı gösterme eğilimindedirler. Ayrıca duygusal zeka ile Sharpe oranları ve getirileri ile ilgili anlamlı bir ilișki bulunamamıștır (Ameriks ve diğ., 2009). Bu bilgilerin ıșığında bu çalıșmada duygusal zekânın bireysel emeklilik fon tercihlerinde önem arz etmesi beklenmektedir.

\subsection{Risk Alma Tutumu}

Barak (2008) hakim görüșün aksine yapılan deneysel çalıșmaların bireylerin karar verme sürecinde çok farklı durumlardan 
etkilendiği ve sınırsız bir șekilde rasyonellikten ayrılabildiğine kanıt sunduğunu aktarmıștır. Ayrıca çalıșmada psikolojiyi temel alan davranıșsal finansta bireyin karar sürecinde irrasyonel davranabileceği yaklașımının benimsendiğini belirtmiștir. Bu nedenle bir yatırımcının kararlarının altında yatan sebeplerin araștırılması açısından risk alma tutumu dikkat çekmektedir. Bireyin risk konusundaki bilgisinin yeterli olup olmamasının, çeșitli faktörlerden etkilendiği varsayılan risk alma tutumunun bireyin yaptığı yatırım tercihlerinin doğru analiz edilebilmesinde önemli olduğu düșünülmektedir.

Nicholson ve diğ. (2005) risk davranıșlarının bireysel farklılık seviyelerinde yüksek oranda çeșitlilik gösterdiğini belirtmiștir ve risk karșısında bireylerin tutumlarını inceleyerek bu davranıșları 3 boyutta sınıflandırmıștır. Bunlar heyecan arayanlar (stimulation seekers), amaç odaklılar (goal achievers) veya kayıptan kaçınanlar (lose avoiders) ve riski uyarlayanlardır (risk adapter). Yazarlar, bu tutumları sergileyen bireylerden sadece birinci gruba dahil olanların gerçekten risk peșinde koșanlar olduğunu, diğer iki grubun ise daha doğru bir șekilde risk aldıklarını belirtmiștir.

Camgöz ve diğ. (2011) borsada yüksek performans sergileyenlerin risk eğilimini kișiliklerinin bir parçası olarak tașıyan bireyler olabildiğini vurgulamıștır. Bu bulgular bireylerin bireysel farklılıklarının yașantılarına, mesleklerine ve yatırım davranıșlarına da yansıyabileceğini düșündürmektedir.

Mayfield ve diğ. (2008) riskten kaçınma ile cinsiyet arasında istatiksel olarak anlamlı ilișki bulamamıștır ancak bayanların genellikle riskten daha çok kaçındıklarını gözlemlemiștir. Nicholson ve diğ. (2005) risk alma tutumunu araștırdığı çalıșmasında risk alma tutumunu etkileyen en güçlü faktörlerin psikolojik ve kișisel farklılıklar olduğunu vurgulamıștır.

Bireysel emeklilik sistemi içinde yeralan katılımcının fon tercihlerini yaparken nelerden etkilendiğinin anlașılması açısından etkili bir faktör olduğu düșünülen risk alma tutumu bireyin risk algısı, risk alma eğilimi ile ilișkilidir. Bireylerin farklı risk alma tutumu sergilemesine sebep olan bu faktörlerin daha iyi bilinmesi bireylerin emeklilik yatırımlarının doğru planlanması ve her bireye kendi 
risk alma tutumuna uygun yatırım alternatiflerinin sunulabilmesi açısından da önem arz etmektedir.

Barak (2008) bireysel yatırımcı porfföylerinin yatırımcının tercihlerini yansıtacağını ve her birinin kișiye özel olduğunu aktarmıșıır. Ayrıca yatırımcının tașıdığı özelliklerin de portföyü etkileyebileceğini ve rasyonel yatırımcı tipinden farklılıklar gösterebileceğini belirtmiștir.

Risk alma tutumunun finansal davranıșlar, risk algısı ve bireyin aldığı kararlar üzerindeki etkisinin detaylı bir șekilde açığa çıkarılmasının finansal danıșmanlık, yatııım danıșmanlığı gibi konularda çalıșan uzmanlara, hizmet verdikleri kișilere özel planlar yapmalarında kolaylık sağlayacağı düșünülmektedir. Ayrıca bireysel emeklilik konusunda da tüm bireylere hitap edebilecek çeșitlilikte ürün sunumuna yardımcı olması beklenmektedir.

Bireysel emeklilik ve katılımcıların risk almaları üzerine yapılmıș yeterli sayıda çalıșma olmamasına karșın literatürde risk alma tutumunun yatırım davranıșı üzerinde raporlanmıș etkisi bu araștırmada da risk alma davranıșının bireysel emeklilik fon tercihlerinde önemli olabileceği beklentisini doğurmuștur. Bu bakımdan Siöberg ve Engelberg (2009) 'dan alınan risk alma tutumu ölçeği araștırmaya dahil edilmiștir.

\subsection{Finansal Okuryazarlık}

Uygur (2012), yatırımların dolayısıyla büyümenin sürdürülebilirliği ve ekonomik dengesizlik gibi konularda tasarrufa dikkat çekmiștir. Araștırmacı, Türkiye'nin cari açığı arkasındaki nedenin tasarruf yetersizliği olduğunu belirtmekte ve özellikle önemli ölçüde artan özel tasarruf açığına değinmektedir. Rooij ve diğ. (2012) birçok hükümetin emeklilik birikiminin yetersizliği sorunuyla karșı karșıya olduğunu ve hane halkının yeterli miktarda tasarruf etmesinin bireysel refah seviyesine etkisinin dıșında kamu politikası üzerinde de etkisi olacağını vurgulamıștır. Ayrıca, devletlerin sosyal güvenlik sistemleri ile kendilerine sağladığı refah seviyesinin daha fazlasına sahip olmayı arzulayan ve tasarruf etmek konusunda bir disipline ihtiyaç duyan bireylerin, bireysel emeklilik sistemlerine ilgileri gün geçtikçe artmaktadır 
Bireylerin finansal okur yazarlık seviyesinin emeklilik planları (Dvorak ve Hanley, 2010; Rooij ve diğ., 2012; Rooij ve diğ., 2011 a), sağlık ve emeklilik planlama (Lusardi ve Mitchell, 2008), borsaya katılım (Rooij ve diğ., 201 lb), katkı esaslı emeklilik planı (Altıntaș, 2009) ile ilișkisi ortaya konmuștur. Rooij ve diğ. (2011 b) finansal okur yazarlık ve finansal çeșitlendirmenin finansal karar verme üzerindeki etkisini gösteren çok az sayıda araștırma olduğunu belirtmekte ve tasarruf, portföy tercihleri, emeklilik planları konularına özellikle dikkat çekmektedir.

Lusardi ve Tufano (2008) finansal okuryazarlığın bireyin aldığı kararlarla ilișkili olduğunu ve daha az bilgiye sahip bireylerin daha maliyetli kararlar aldıklarını belirtmiș̦tir. Araștırmaya konu olan birçok hane halkının birikim yapmak ve yatırım kararları almak için gerekli olan en temel ekonomik bilgilere bile așina olmadığını tespit etmișlerdir. Araștırmacıların Amerika ve diğer ülkelerdeki genç ve yașlı insanların ne yazık ki temel finansal terimler konusunda dahi yetersiz bilgiye sahip oldukları görülmektedir. Bu da emeklilik planlaması ve birikim gibi konularda daha iyi kararlar alabilmek için finansal bilgi sahibi olmanın ne denli önemli olduğunu göstermiș̦tir (Lusardi ve Mitchell, 2007).

Günümüzde bireylerin mal varlıklarını yönetmeleri ve portföy tercihleri yirmi ya da otuz yıl öncesine göre çok daha fazla bilgi gerektirecek hale gelmiștir (Rooij ve diğ., 2012). Bir diğer çalıșmada da bireylerin finansal piyasada gittikçe aktif hale gelmelerinin ve piyasaya katılımlarının yeni finansal servis ve ürünlerin gelișimine ön ayak olduğu belirtilmiștir (Rooij ve diğ., 2011b). Finansal ürünlerin daha çeșitli ve kompleks hal almasına karșın yakın zamanda yapılan çalıșmalar, finansal okuryazarlığın önemli ölçüde düșük olduğunu vurgulamaktadır (Dvorak ve Handley, 2010; Lusardi ve Mitchell, 2007a). Rooii ve diğ. (201 lb) düșük finansal okuryazarlığa sahip bireylerin aile ve arkadaș çevrelerinden aldıkları tavsiyelere güvenme ve bu doğrultuda yatırım yapma konusunda daha fazla eğilimli olduklarını gözlemlemiștir.

Rooij ve diğ. (201 1b) finansal okuryazarlığın cinsiyet, eğitim ve yașa göre farklılık gösterdiğini belirtmiștir. Çalıșmanın en önemli sonucu olarak düșük finansal okuryazarlık seviyesindeki 
bireylerin hisse senedi yatırımı yapmadıkları olarak belirtilmiștir. Rooij ve diğ., (2012) finansal okuryazarlık ile mal varlığı biriktirme arasında pozitif bir ilișki tespit etmiștir. Bu ilișkiye iki yolla açıklama getirmișlerdir. Bunlardan ilki finansal bilginin bireylerin borsa yatıımını artırması, diğeri de finansal okuryazarlık ile emeklilik planlaması arasında pozitif ilișkinin tespit edilmesi olmuștur. Dolayısıyla bireyin yatırım planlarını geliștirmek suretiyle daha fazla mal varlığına sahip olabileceği de belirtilmiștir.

Hilgert, Hogart ve Beverly (2003) finansal olarak bilgi sahibi tüketicilerin aileleri için daha iyi karar verebilmekte olduğunu, böylelikle ekonomik olarak güvencelerini ve refah seviyelerini artırıc bir tutum sergileyebileceklerini belirtmiștir. Araștırmacılar, yatırım bilgisi ve tasarruf bilgisi arasında anlamlı bir ilișki olduğu sonucuna ulașmıșlardır.

Bayer ve diğ. (1996) çalıșanların emeklilik seminerleri ile bilgilendirildikleri durumlarda gönüllü birikim planlarına katıldıklarını gözlemlediklerini ve eğitim seminerlerinin sıklığı ve emekliliğe katılım oranı arasında güçlü bir ilișki bulduklarını belirtmișlerdir.

Lusardi ve Mitchell (2008), yașlı kadınların finansal okuryazarlık seviyesinin düșük olduğunu ve kadınların büyük bir kısmının emeklilik için bir planlarının olmadığını ortaya koymuștur. Ayrıca, finansal bilgi ve planlama arasında belirgin bir ilișki gözlemlenmiștir ve yüksek finansal okuryazarlığa sahip olan kadınların büyük olasıııkla bașarılı birer planlayıcı oldukları belirtilmiștir.

Rooij ve diğ. (201 1b) yaptığı araștırmaya katılanların pek çoğunun temel finansal bilgiye; çok az bir kısmının temel bilgiden daha fazlasına sahip olduklarını ifade etmektedir. Çalıșmada, düșük finansal okuryazarlık seviyesine sahip katılımcıların hisse senetlerine daha az yatırım yapmayı tercih ettikleri gözlemlenmiștir. Bunun nedeni olarak borsa ve çalıșma sistemi hakkında çok az bilgiye sahip olmalarını ileri sürmüșlerdir.

Millar ve Devonish (2009) araștırmalarında katılımcıların çoğunun emeklilik ve emeklilik planlamasıyla ilgili tavsiye aldıklarını iddia etmelerine rağmen emeklilik planı kararlarını etkileyen çok temel bilgileri dahi bilmedikleri sonucuna ulașmıșlardır. Ayrıca ça- 
lıșanların iș arkadașlarından gelen tavsiyelere daha çok güvendiklerini fakat kültürel farklılıklar ve toplumun bireyci-kollektif bilince sahip olmasının bu durum üzerinde etkili olabildiğini, kollektif toplumlarda bilginin aile, arkadașlar ve meslektașlar arasında daha fazla paylașılmakta olduğunu belirtmișlerdir. Ayrıca, çalıșanların büyük bir kısmının özellikle de düșük gelirli olanların emeklilik için ne kadar birikime ihtiyacı olduklarını planlamadıkları ortaya konmuștur.

Dvorak ve Handley (2010) zayıf yapılandırılmıș portföylere katılımcıların yatırım tercihlerini anlamamalarının sebep olabileceğini belirtmiș ve bilgilendirme ile portföylerdeki yatırımların iyileștirilebileceği ifade edilmiștir.

Mevcut literatürün finansal okuryazarlığın genel olarak finansal özel olarak emeklilik planlamasına olan etkisini ortaya koyması, bireysel emeklilik fon tercihleri üzerinde de finansal okuryazarlığın önemli olabileceği beklentisini olușturmaktadır. Buradan hareketle, Rooij ve diğ. (2011) finansal okuryazarlık ölçeği çalıșmaya dâhil edilmiștir.

\subsection{Demografik Faktörler}

Bireylerin yatıım kararlarını ve risk alma konusundaki eğilimlerini etkileyen sebepleri araștıran çalıșmaların pek çoğuna demografik faktörler de konu olmuștur. Barak (2008) yatırımcı özelliklerinin demografik özelliklerden büyük oranda etkilendiğini belirtmiștir. Bu araștırmada da katılımcıların cinsiyet farklılıklarının, yașının, medeni durumunun ve eğitim seviyesinin yatırım kararları üzerinde herhangi bir etkisi olup olmadığı literatürdeki önemlerine istinaden dikkate alınmıștır.

Grable ve Roszkowski (2007) kadınların erkeklere göre daha fazla riskten kaçındığını belirtmiștir. Arano ve diğ. (2010) ise kadınların emeklilik yatırımlarının büyük bir kısmını hisse senedi üzerinde değerlendirdikleri yönünde delil sunmușlardır. Bu sonucu göz önünde tutarak erkekler ile kıyaslandığında kadınların, istatiksel olarak anlamlı düzeyde riskten çok da fazla kaçınmadıklarının gözlemlendiğini belirtmișlerdir. 
Peegs (2000) ise emeklilik tasarrufları üzerine yaptığı araștırmasında kadınların, emeklilik konusunda tasarruf yapmayı bir zorunluluk olarak gördüklerini, hatta çok az geliri olanlarda bile birikim yapanların görülebileceğini söylemiștir. Bu sonucu yorumlarken, çoğu kadını çevresinden ziyade kendi ihtiyaçlarının yönlendirdiğine değinmiștir.

Șahin ve diğ. (2010) bireylerin aktif çalıșma yıllarında sisteme bireysel katılımları ile emeklilik maașları arasında doğrudan ilișki olduğunu ve kadınların erkeklere oranla daha düșük gelir elde etmesinin muhtemel olduğunu belirtmiștir. Speelman ve diğ. (2013) düșük riskli yatırım yapmaya yüksek oranda meyil gösteren kadınların bu davranıșsal eğilimlerinin eğitimle değiștirilememesi durumunda, emeklilik döneminde yeterli tasarruf yapamamıș olma sonucu ile karșı karșıya kalabileceklerini belirtmiștir. Clark ve Strauss (2008) ise kadınların erkeklerden daha fazla riskten kaçındığını belirtmișlerdir.

Gibson ve diğ. (2013) kadınlarda ve yașlı bireylerde finansal risk tolerans seviyesinin diğer bireylere göre daha az olduğunu vurgulamıștır. Watson ve McNaughton (2007)'e göre kadınlar genellikle erkeklerden daha fazla riskten kaçınmakta ve daha tutucu yatırım stratejileri izlemektedir.

Medeni durum, finansal alanda yapılan araștırmalara konu olan bir diğer demografik faktördür. Arano ve diğ. (2010) evli çiftlerde risk alma konusunda eșlerin birbirini etkilemesi ile ilgili farklılığı özetlemișlerdir. Buna göre, evli çiftlerde erkeklerin eșlerini risk almaya yönlendirmesi durumunda kadıların daha fazla riskten kaçındığı ancak kadınların eșlerini risk almaya yönlendirmesi durumunda erkeklerin daha fazla risk aldığı gözlemlenmiștir.

Gibson ve diğ. (2013)'e göre, daha önceki akademik çalıșmaların gösterdiğinin aksine finansal risk toleransı ve evlilik durumu, eğitim ve refah seviyesi arasında anlamlı bir ilișki bulunamamıșıır. Aynı șekilde Clark ve Strauss (2008) evlilik durumunun risk toleransını az ya da çok etkilediğine dair bir bulgu elde edememișlerdir. 
Yılmazer ve Lyons (2010) finansal kaynaklar üzerinde fazla kontrole sahip evli kadınların emeklilik yatıımlarında riskli yatıııları daha az tercih ettiğini belirtmiștir. Çalıșmada aynı zamanda yașlı erkeklerle evli olan kadınların emeklilik yatırımlarında daha az risk almaya eğilimli oldukları fakat buna karșın evli kadınların karakterlerinin eșlerinin yatıım kararlarına etkisini gösteren çok fazla kanıt olmadığı aktarılmıștır.

Dikkate alınan bir diğer demografik faktör de katılımcıların yașlarıdır. Dulebohn (2002) bireylerin yașlandıkça yatıım kayıplarını telafi etme konusunda artan endișelerinden dolayı yüksek orandaki risklerden kaçındıklarını ve emeklilik yatııımlarının büyük kısmını daha az riskli yatırımlara ayırmayı tercih ettiklerini belirtmiștir. Barak (2008) yașın yatırımcıların risk ve getiri tercihlerinin önemli bir göstergesi olabileceğini belirtmiștir. Aynı çalıșmada bireylerin hayatlarının dört bölüme ayrılabileceği aktarılmıștır. Bu dönemler, biriktirme (gençlik dönemleri ve riskli yatırımların tercih edildiği dönem), serveti sağlama alma (gelirin gideri aștığı, riskli yatıımların yanı sıra düșük riskli yatııım araçlarının da tercih edildiği dönem), harcama (yatırım yapma süresinin azaldığını düșünen yatııımcının daha az riskli yatırımlara yöneldiği dönem) ve ödül dönemi (sahip olduklarını korumak istedikleri dönem) olarak adlandırılmıștır.

Camgöz ve diğ. (2011)'e göre yüksek finansal performans sergileme ihtimali yaș arttıkça azalmıștır. Ayrıca, genç fon yöneticilerinin hedefe doğru daha güçlü bir yönelime sahip olmasının daha büyük bașarılar elde etmelerine olanak sağlayabilecek nedenlerden biri olabileceğini belirtmiștir. Clark ve Strauss (2008) ise araștırmasında yașlı insanların orta yașlı insanlara oranla daha az riskten kaçtı̆̆ına değinmiștir.

Araștırmaya dahil edilen bir diğer demografik faktör ise eğitim durumudur. Rana ve diğ. (2014) bilgi araștırma davranıșı ve eğitim seviyesi arttıkça riskli varlıklara yatırım yapma eğiliminin arttığını gözlemlemișlerdir. Gibson ve diğ. (2013) finansal risk toleransı ve eğitim arasında anlamlı bir ilișki tespit edememișlerdir. Ancak yüksek yatırım bilgi seviyesinin yüksek finansal risk toleransı ile ilișkisi olduğunu göstermișlerdir. 


\section{Yöntem}

\subsection{Amaç}

Bu çalıșmanın amacı duygusal zekâ, risk alma, finansal okuryazarlık ve demografik faktörlerin bireylerin bireysel emeklilik fon tercihleri üzerindeki önemini tespit etmek ve finansal danıșmanlara yatırımcılara tavsiyelerde bulunurken rehber olabilecek bileșenleri belirlemektir. Ayrıca, bireysel emeklilik yatırımlarına yönelik bireylerin risk algısının hisse senedi, tahvil ve hisse senedi-tahvil eșit ağırlıklı fon bileșimine göre değișip değișmediğini ortaya koymaktır.

\subsection{Veri}

Araștırmada veri toplama yöntemi olarak anket kullanılmıștır. Çalıșma örneklemi Bursa, Ankara, Adana ve İstanbul'da yașayan 214 sayıda katılımcıyı içermektedir. Katılımcılar, kamu ve özel sektör çalıșanlarından, öğrencilerden ve çalıșma hayatında yer almadığı halde bireysel emeklilik sistemine dâhil olan bireylerden olușmaktadır. Katılımcılara, hazırlanmıș olan anketler posta ve elektronik ileti yoluyla ulaștırılmıștır.

\subsection{Değișkenler}

Bu araștırmada 5 adet değișken yer almaktadır: Duygusal zekâ, risk alma tutumu, temel-ileri finansal okuryazarlık, demografik faktörler (örneğin yaș ve eğitim) bağımsız değișken olarak, hisse senedi ağırlıklı, tahvil ağırlıklı ve eșit ağırlıkı fon düzeylerinden olușan bireysel emeklilik fon bileșimi bağımlı değișken olarak yer almıștır.

Duygusal zekâ ölçeği olarak Schutte ve diğ. (1998)'den alınan tek boyutlu olarak geçerliliği sağlanmıș 33 maddelik ölçek kullanılmıștır. Bu 33 madde, duygusal zekânın duyguların fark edilmesi, duyguların düzenlenmesi ve duyguların kullanımı olmak üzere 3 boyutunu da içermektedir. Finansal okuryazarlık ölçeği olarak Rooii ve diğ. $(2011)$ 'den istifade edilmiștir. Buna göre finansal okuryazarlık ölçeği olan 16 doğru cevabı olan sorulardan olușmaktadır. Temel ve ileri finansal okuryazarlık olmak üzere 2 
bölümden olușmaktadır. Illk 5 soru temel finansal bilgi düzeyini, diğer 11 soru ise ileri finansal bilgi seviyesini ölçmektedir. Risk alma tutumu ölçeği olarak Sjöberg ve Engelberg (2009) 'den yararlanılmıșıır. Söz konusu ölçek, 22 maddeden olușmaktadır.

Ayrıca, risk algısının hisse senedi, tahvil ve eșit ağırlıklı fon bileșimine göre değișip değișmediğini incelemek üzere Sachse ve diğ. (2012)'den alınan risk algısı ölçeği kullanılmıștır. Toplam 12 sorudan olușan ölçekte bireylerin belirli bir yatıııma ilișkin riski hangi yönleriyle algıladıklarının ölçülmesi amaçlanmıștır. Söz konusu ölçeğin maddeleri, araștırma sorusu olan bireysel emeklilik fon tercihlerine uyarlanmıștır.

\subsection{Analizler}

\subsubsection{Geçerlilik ve Güvenilirlik Analizi}

Çalıșmamızdaki bağımsız değișkenler, duygusal zekâ (33) ve risk alma davranıșına (22) ilișkin toplam elli beș soru, topluca keșifsel faktör analize tabi tutulmuștur. Keșifsel faktör analizinin yapılmasının temel sebebi, soruların orijinalinden Türkçeye çevrilmesi ve çalıșmamıza ilișkin uyarlamaların yapılmıș olmasıdır. Diğer bağımsız değișkenimiz finansal okuryazarlık ise puan olarak hesaplandığı için faktör analizine dâhil edilmemiștir.

Faktör analizi sonuçları Tablo 3.1'de görülmektedir. Teorik bilgilerimizle uyumlu iki faktör olușmuștur. Verilerin faktör analizine uygunluğunu için yapılan Bartlett küresellik (sphericity) testi değeri 4.430,468 olarak hesaplanmıș ve 0,000 seviyesinde anlamlı bulunmuștur. KMO (Kaiser Meyer Olkin) değeri 0,856 hesaplanarak örneklem büyüklüğ̈nün yeterli olduğu kabul edilebilir. Ayrıca faktörlerin güvenirlik analizleri yapılmıș ve oldukça yüksek seviyede güvenirlik değerleri hesaplanmıștır. 
Tablo 3.1. Faktör ve Güvenirlik Analizi

\begin{tabular}{|c|c|c|}
\hline \multirow{3}{*}{$\begin{array}{l}\text { KMO } \\
\text { Bartlett } \\
\text { Sorular }\end{array}$} & \multicolumn{2}{|c|}{0,856} \\
\hline & \multicolumn{2}{|c|}{$4.430,468(0,000)$} \\
\hline & Duygusal Zekâ & Risk Alma Davranıșı \\
\hline El &, 514 & \\
\hline E2 &, 603 & \\
\hline E3 & ,693 & \\
\hline E4 & ,577 & \\
\hline E5 & 481 & \\
\hline E6 &, 560 & \\
\hline E7 & ,495 & \\
\hline E8 &, 519 & \\
\hline E9 &, 588 & \\
\hline E10 &, 539 & \\
\hline E12 &, 564 & \\
\hline E13 &, 441 & \\
\hline E14 & ,602 & \\
\hline E15 & ,541 & \\
\hline E16 &, 589 & \\
\hline E17 & ,613 & \\
\hline E18 &, 595 & \\
\hline E19 &, 576 & \\
\hline E20 & ,616 & \\
\hline E21 & 481 & \\
\hline E22 &, 532 & \\
\hline E23 &, 510 & \\
\hline E25 & ,575 & \\
\hline E26 & ,495 & \\
\hline E27 &, 565 & \\
\hline E28 &, 526 & \\
\hline E30 &, 522 & \\
\hline E31 &, 583 & \\
\hline E32 & 639 & \\
\hline E33 &, 539 & \\
\hline R1 & & ,705 \\
\hline R2 & & 707 \\
\hline
\end{tabular}




\begin{tabular}{|c|c|c|}
\hline R3 & &, 637 \\
\hline R4 & &, 636 \\
\hline R5 & &, 548 \\
\hline R6 & &, 665 \\
\hline R7 & &, 580 \\
\hline R8 & &, 535 \\
\hline R12 & &, 643 \\
\hline R13 & &, 489 \\
\hline R14 & &, 559 \\
\hline R16 & &, 568 \\
\hline R19 & &, 480 \\
\hline Güvenirlik Analizi & 0,929 & 0,890 \\
\hline
\end{tabular}

\subsubsection{Diskriminant Analizi}

Bireysel emeklilik sözleșmesine sahip bireylerin seçtikleri fon bileșiminin sebeplerini açıklamak ve finansal danıșmanların bireysel emekliliğe yeni katılacak bireylere uygun fon bileșimi tavsiye etmelerine yol gösterecek değișkenleri belirlemek için diskriminant analizi yapılmıștır. Analize bağımlı değișken olarak fon bileșimi alınırken yaș, eğitim düzeyi, duygusal zekâ, risk alma davranıșı, temel ve finansal okuryazarlık seviyesi de bağımsız değișkenlerdir.

Tablo 3.1. Faktör ve Güvenirlik Analizi

\begin{tabular}{|l|c|c|c|c|c|c|c|c|}
\hline & \multicolumn{2}{|c|}{ H.S. } & \multicolumn{2}{c|}{ Tahvil } & \multicolumn{2}{c|}{ Eșit } & \\
\hline & Ort. & S.S. & Ort. & S.S. & Ort. & S.S. & $\begin{array}{c}\text { Wilks' } \\
\text { Lambda }\end{array}$ & Anlam \\
\hline Yaș & 2,06 & 0,66 & 2,11 & 0,97 & 1,84 & 0,80 & 0,98 & 0,100 \\
\hline Eğitim & 2,37 & 0,94 & 2,55 & 0,85 & 2,71 & 0,77 & 0,97 & 0,047 \\
\hline Duygusal Zeka & 3,86 & 0,49 & 3,61 & 0,56 & 3,80 & 0,44 & 0,97 & 0,035 \\
\hline Risk Alma Davranıșı & 3,40 & 0,60 & 3,14 & 0,78 & 3,17 & 0,65 & 0,98 & 0,079 \\
\hline Tem.Finan. Okuryazarlık & 2,19 & 1,43 & 2,00 & 1,60 & 2,03 & 1,63 & 1,00 & 0,798 \\
\hline Ileri Finan. Okuryazarlık & 3,39 & 2,73 & 3,86 & 3,20 & 3,42 & 3,04 & 1,00 & 0,669 \\
\hline
\end{tabular}

Yukarıdaki tabloda bağımlı değișken ve her bir alt kategorisi için ilgili değișkenlerin ortalama ve standart sapma değerleri verilmiștir. Ayrıca ilgili alt gruplar için bağımsız değișkenlerin or- 
talama değerlerinin birbirlerinden farklı olup olmadı̆̆ını test etmek için Wilks Lambda değerleri hesaplanmıș rapor edilmiștir. Tablodan görüleceği gibi temel ve ileri finansal okuryazarlık puanı haricinde bütün değișkenler 0,10 hata payı ile her bir emeklilik fon bileșiminde farklılık göstermektedir. Yaș tam 0,10 hata payında anlamlıdır eğitim seviyesi ve duygusal zeka ise 0,05 hata payı ile de üç grup için birbirine eșit kabul edilemez. Genel olarak değerlendirildiğinde kișilerin finansal okuryazarlık seviyelerine göre bireysel emeklilik fon tercihlerinin değișmediği ifade edilebilir.

Tablo 3.3. Özdeğerler

\begin{tabular}{|c|c|c|c|c|c|}
\hline Fonksiyon & Özdeğer & \% of Varyans & Kümülatif \% & Wilks' Lambda & Anlamlılık \\
\hline 1 &, 079 & 62,4 & 62,4 &, 884 &, 016 \\
\hline 2 &, 048 & 37,6 & 100,0 &, 954 &, 096 \\
\hline
\end{tabular}

Diskriminant analizinde bağımlı değișkenin kategori sayısından bir eksiği kadar fonksiyon olușturulur. Bizim çalıșmamızda üç kategori olduğu için iki fonksiyon olușturulmuștur. Yukarıdaki tabloda her iki fonksiyonun öz değerleri, varyans açıklama oranları ve anlamlılıkları görülmektedir. Birinci fonksiyonun varyans açıklama oranı \%62,4 iken ikinci fonksiyonun \%37,6'dır. Görüleceği gibi 0,05 hata payı ile varyansın \%62,4'ünü açıklayan ilk fonksiyon anlamlıdır. İkinci fonksiyonun ise ancak 0,10 hata payında anlamlı olabilmektedir.

Tablo 3.4. Yapı Matrisi

\begin{tabular}{|l|c|c|}
\hline \multirow{2}{*}{} & \multicolumn{2}{|c|}{ Fonksiyon } \\
\cline { 2 - 3 } & $\mathbf{1}$ & $\mathbf{2}$ \\
\hline Eğitim &,$- 598^{*}$ &, 211 \\
\hline Risk Alma Davranıșı &, $537^{*}$ &, 227 \\
\hline Yaș &, $157^{*}$ &, 073 \\
\hline Temel Finansal Okuryazarlık &, 244 &, $776^{*}$ \\
\hline Duygusal Zeka &, 351 &,$- 525^{*}$ \\
\hline ileri Finansal Okuryazarlık &,- 040 &,$- 284^{*}$ \\
\hline
\end{tabular}


Yukarıdaki tablo bağımsız değișkenlerin hangi fonksiyonda daha yüksek ayırma anlamlılığına sahip olduğunu gösterir. Daha fazla açıklama oranına ve anlamlılığa sahip birinci fonksiyonda eğitim, risk alma davranıșı ve yaș daha önemlidir. İkinci fonksiyonda ise temel ve ileri finansal okuryazarlık ile duygusal zekâ ön planda yer almaktadır.

Tablo 3.5. Kanonik diskriminant fonksiyonu katsayıları

\begin{tabular}{|l|c|c|}
\hline \multirow{2}{*}{} & \multicolumn{2}{|c|}{ Fonksiyon } \\
\cline { 2 - 3 } & $\mathbf{1}$ & $\mathbf{2}$ \\
\hline Yaș &, 476 &,- 464 \\
\hline Eğitim &,- 833 &, 240 \\
\hline Duygusal Zeka &, 382 & 1,532 \\
\hline Risk Alma Davranıșı &, 925 &, 001 \\
\hline Temel Finansal Okuryazarlık &, 274 &, 192 \\
\hline İleri Finansal Okuryazarlık &,- 039 &,- 196 \\
\hline (Sabit) & $-3,627$ & $-5,211$ \\
\hline
\end{tabular}

Yukarıdaki tablo alt grupları birbirinden ayırmada kullanılacak diskriminant fonksiyonun katsayılarını verir. Buradan hareketle birinci ve ikinci fonksiyon șu șekilde yazılabilir:

Tablo 3.6. Fonksiyonların Gruplardaki Ağırlık Merkezleri

\begin{tabular}{|l|c|c|}
\hline \multirow{2}{*}{} & \multicolumn{2}{|c|}{ Fonksiyon } \\
\cline { 2 - 3 } & $\mathbf{1}$ & $\mathbf{2}$ \\
\hline Hisse Senedi &, 460 &, 072 \\
\hline Tahvil &,- 062 &,- 414 \\
\hline Eșit &,- 205 &, 132 \\
\hline
\end{tabular}

Diskrimant fonksiyonu yardımı ile hesaplanan değerler bireyin hangi gruba dâhil olacağını gösterir. Bunun için yukarıdaki tablodaki ağırlık merkezleri yardımıyla da ayırma (kesișme) noktaları hesaplanır. 


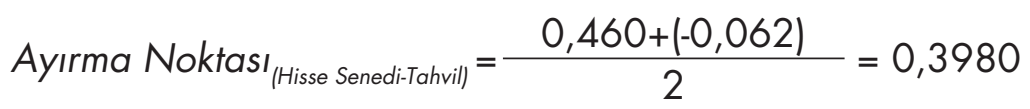

Ayırma NoktasI $\left.\right|_{\text {Hisse Senedi-Esit) }}=\frac{0,460+(-0,205)}{2}=0,1275$

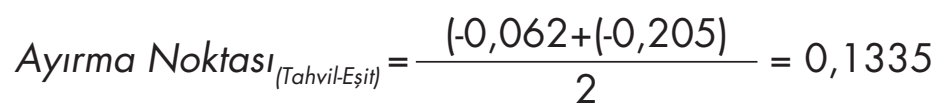

Buna göre Fonksiyon Değeri >0,3980 Hisse Senedi Ağırlıklı Fon

0,3980>Fonksiyon Değeri >0,1275 Tahvil Ağırlıklı Fon

0,1275>Fonksiyon Değeri >-0,1335 Eșit Ağılık Fon

Ayrıca yine bu fonksiyon yardımı ile yeni bireylerin ilgili değișken değerleri girilerek fonksiyon değeri hesaplanabilir ve bireysel emeklilik fon tercihinde hisse senedi veya tahvil ağırlıklı yahut eșit dağılımlı portföylerin tercih edebilecek olması öngörülebilir.

Tablo 3.7. Sınıflama Sonuçları

\begin{tabular}{|c|c|c|c|c|c|}
\hline & & \multicolumn{3}{|c|}{ Tahmin Alt Grup Üyeleri } & \multirow{2}{*}{ Toplam } \\
\hline & & 2 & 3 & & \\
\hline \multirow{4}{*}{ Adet } & 1 & 28 & 14 & 12 & 54 \\
\hline & 2 & 14 & 20 & 10 & 44 \\
\hline & 3 & 31 & 23 & 54 & 108 \\
\hline & Gruplanmamıș & 1 & 1 & 1 & 3 \\
\hline \multirow{4}{*}{$\%$} & 1 & 51,9 & 25,9 & 22,2 & 100,0 \\
\hline & 2 & 31,8 & 45,5 & 22,7 & 100,0 \\
\hline & 3 & 28,7 & 21,3 & 50,0 & 100,0 \\
\hline & Gruplanmamıș & 33,3 & 33,3 & 33,3 & 100,0 \\
\hline
\end{tabular}

Yukarıdaki tablodan hareketler doğru sınıflama oranı $(28+$ $20+54) /(54+44+108)=\% 49,5$ olarak hesaplanabilir. Bu sınıflandırma oranının kabul edilebilir olup olmadığını ifade edebilmek için tesadüfi sınıflandırma ile elde edilecek doğru sınıflandırma oranına bakmak gerekir. Tesadüfi sınıflandırmadan elde edilecek doğru sınıflandırmaların sayısını ve oranını hesaplayabil- 
mek için Morrison'un önerdiği șans modeli kullanılacaktır (Kurtuluș, 1998, s:477 Aktaran: Yeniçeri, 2005);

Doğru Sinflama $=\left(\frac{54}{206}\right) \times\left(\begin{array}{c}73 \\ 206\end{array}\right)+\left(\begin{array}{c}44 \\ 206\end{array}\right) \times\left(\frac{57}{206}\right)+\left(\begin{array}{c}108 \\ 206\end{array}\right) \times\left(\begin{array}{c}76 \\ 206\end{array}\right)$

Doğru Sınıflama $=0,093+0,059+0,193=0,345$

Buradan hareketle tesadüfi sınıflandırmanın doğru sınıflandırma oranının \%34,5 olduğu söylenebilir. Nakip (2006) yapılan sınıflandırmanın bașarılı kabul edilebilmesi için șanslı sınıflandırmanın en az \%25 fazlası olması gerektiğini belirtir. Buna göre șanslı sınıflandırmanın \%25 fazlası 0,431 (0,345 x 1,25)'dir ve analiz sınıflandırmamız bu değerin üstündedir. Bu șekilde diskriminant analizi ile elde ettiğimiz fonksiyon kullanılarak yapılan sınıflandırmanın kabul edilebilir bir düzeyde olduğunu ifade etmek mümkündür.

\subsubsection{ANOVA Testi}

Çalıșmada risk alma davranıșının yanı sıra Sache vd.(2012) takip edilerek her bir fonu tercih eden bireylerin algıladıkları risklerin fon tercihine göre değișip değișmediği araștırılmıștır. Diskriminant analizinde risk alma tutumu ile konu açıklanmaya çalıșılmıștır. Risk algısı ile risk alma davranıșı birbiri ile ilișkili ancak farklı kavramlardır. Aynı anda her iki değișkenin bağımsız değișken olarak analize girmesi yüksek otokorelasyona sebep olacak ve testleri olumsuz etkileyecektir. Bu sebeple literatürde daha yaygın șekilde ilișki kurulan risk alma davranıșı diskriminant analizinde bağımsız değișken olarak kullanılmıștır. Bununla birlikte risk algısının da fon tercihinde etkili bir değișken olabileceği gerçeğinden hareketle ikinci ve farklı bir analiz ile konu diğer yönleri ile de ele alınmaya çalıșı ımıștır. 
Tablo 3.8. Ortalama, S.S. ve Anova Test Değerleri

\begin{tabular}{|l|c|c|c|c|c|c|c|}
\hline & \multicolumn{2}{|c|}{ Hisse Senedi } & \multicolumn{2}{|c|}{ Tahvil } & \multicolumn{2}{c|}{ Eșit } & Anova \\
\hline Değișken & Ort. & S.S. & Ort. & S.S. & Ort. & S.S. & Anlam. \\
\hline Algılanan Risk & 2,13 & 1,04 & 2,04 & 1,00 & 2,37 & 1,05 & 0,133 \\
\hline Tahmin Edilebilirlik & 3,42 & 0,74 & 3,24 & 0,98 & 3,23 & 0,92 & 0,409 \\
\hline Dikkat & 2,78 & 1,23 & 2,49 & 1,24 & 2,86 & 1,22 & 0,223 \\
\hline Endișe & 3,47 & 1,02 & 2,87 & 1,36 & 3,58 & 1,2 & $0,003^{* *}$ \\
\hline Kayıp Olasılı̆̆ı & 3,33 & 0,96 & 2,98 & 1,08 & 3,08 & 1,12 & 0,226 \\
\hline Kayıp Miktarı & 3,53 & 1,00 & 3,38 & 0,96 & 3,15 & 1,06 & $0,066^{*}$ \\
\hline Toplam Kayıp Olasılı̆̆ı & 2,67 & 1,23 & 2,56 & 1,41 & 2,55 & 1,12 & 0,808 \\
\hline Değișkenlik & 3,35 & 0,97 & 3,36 & 1,09 & 3,41 & 1,05 & 0,918 \\
\hline Likidite & 3,05 & 1,16 & 3,04 & 1,15 & 3,11 & 1,14 & 0,932 \\
\hline Yenilik & 3,29 & 1,21 & 3,51 & 1,12 & 3,18 & 1,14 & 0,276 \\
\hline Șeffaflık & 3,31 & 0,98 & 2,93 & 1,12 & 3,10 & 0,91 & 0,154 \\
\hline Yatııım İsteği & 3,85 & 0,78 & 3,96 & 1,09 & 3,57 & 1,00 & $0,046^{* *}$ \\
\hline
\end{tabular}

Sache ve diğ. (2012) algılanan riski her biri bir soru ile ölçülmek kaydı ile 12 farklı özellik ile değerlendirmiștir. Bireysel emeklilik fon tercihlerinde hisse senedi veya tahvil ağılıklı yahut eșit dağılımlı tercihte bulunanların algıladıkları riskin her bir özelliğine ilișkin ortalama ve standart sapma değerleri tabloda verilmiștir. 0,05 hata payı ile "endișe" ve "yatırım isteği" ve 0,10 hata payı ile "kayıp miktarı" farklı fon tercihinde bulunan bireylerde istatistiksel olarak anlamlıdır. Yapılan Duncan Analizleri neticesinde "endișe" değișkeni tahvil ağırlıklı fon seçenlerde diğer iki alternatifi seçenlere göre istatistiksel olarak daha düșüktür. Tahvil getirisi sabit bir yatırım aracı olarak kabul edildiği için istatistiksel olarak elde edilen bu bulgular teorik olarak da son derece tutarlıdır.

ikinci farklılık yaratan değișken ise "yatııım isteği"dir. Bireysel emekliliğe yatırım yapma isteği yüksek kișiler hisse senedi veya tahvil ağırlıklı fon olușturmayı tercih etmektedir. Buna karșılık bireysel emeklilipe yatırım isteği düșük kișiler eșit ağırlıklı fonu tercih etmektedir. Öneklemimizin yaklașık yarısının tercihi de eșit ağırlıklı fondan yanadır. Bu konu ile ilișkilendirilebilecek bir diğer husus ise finansal okuryazarlık seviyesidir. Çalıșmamızda kullanı- 
lan finansal okuryazarlık ölçeğinin sahibi Rooij vd. (2011) çalıșmasında temel finansal okuryazarlık ortalama puanı 3,94 ve ileri finansal okuryazarlık ortalama puanı 5,93 iken bizim örneklemimizde 2,04 ve 3,06 olarak hesaplanmıștır. Ayrıca bu değerlerin Rooij vd. (2011) ortalamalarından istatistiksel olarak farklı olup olmadığı one sample $t$ test ile araștııılmıș ve istatistiksel olarak daha düșük olduğu tespit edilmiștir. Bu bulgular neticesinde risk algısının bir boyutu olan "yatırım isteği"nin eșit dağılımlı planda düșük çıkmasının sebebi bireylerin porfföy olușturma bilgisinden mahrum olmaları ile açıklanabilir.

Son olarak "kayıp miktarı" ortalama değeri yine eșit dağılımlı planda daha düșüktür. Teori ile de tutarlı bu bulgu portföy mantığı ile olușturulan planların kayıp miktarının diğerlerinden daha düșük olduğu bulgusunu desteklemektedir.

\section{Sonuç ve Değerlendirme}

Bu çalıșmanın amacı kișilerin bireysel emeklilik sisteminde fon tercihlerinde etkili olan değișkenleri belirlemek ve finansal danıșmanlara, bireylere tavsiyede bulunurken rehberlik edecek unsurları göstermektir. Bu çerçevede bireysel emeklilik sistemine katılmıș bireylerden anket yolu ile çeșitli demografik özelliklerine, duygusal zekâlarına, risk alma davranıșları, risk algılarına ve finansal okuryazarlık seviyelerine ilișkin bilgiler toplanmıștır. Çalıșmamızda fon tercihine göre risk algısının değișip değișmediği yapılan anova analizleri ile test edilmiștir. Analizler neticesinde oniki boyutla değerlendirilen risk algısının yatııı isteği, kayıp miktarı ve endișe boyutları fon tercihine göre değișmekte, diğer boyutlar ise fon tercihinden bağımsız değișmektedir. Tercih edilen fon türüne ilișkin endișe duygusu en düșük tahvil ağırlıklı fon seçimi yapanlar görülmektedir. Hisse senedi ağırlıklı ve eșit ağırlık fon tercihi yapanlarda endișe duygusu daha güçlüdür. Teori ile oldukça tutarlı bir bulgu elde edilmiștir. Tahvil nominal getirisi sabit bir yatırım aracıdır. Özellikle bireysel emeklilik gibi uzun vadeli yatırımlarda bașta öngörülen nominal getiri elde edilecektir. Bu sebeple tahvil ağırlıkı fon tercihinde bulunan bireylerin daha az endișe duyması normal bir davranıș olarak kabul edilebilir. Elbette nominal getiri- 
nin yanı sıra reel getirinin de dikkate alınması gerekir. Bu çerçeveden bakılınca cari faizlerde ve/veya enflasyon oranındaki yükselișe paralel olarak tahvil ağırlıklı fon tercihinde bulunan bireylerin de endișelenmesi gerekebilir. Çalıșmamızda da vurgulandığı gibi bizim örneklemimiz bireysel emeklilik sistemine katılmıș kișilerden olușmakla birlikte ölçülen finansal okuryazarlık seviyeleri oldukça düșük seviyededir. Bu sebeple düșük finansal okuryazarlığa sahip kișilerden reel getiri kavramını bilmeleri de beklenmemelidir. Zaten çalıșmamızın farklı noktalarında düșük finansal okuryazarlık ile ilișkilendirilebilecek bulgular sağlanmıștır.

Bireysel emeklilik sistemine yatırım isteği de fon tercihine göre değișmektedir. Hisse senedi ve tahvil ağrılıklı fon tercih etmiș kișilerin sisteme katılma istekleri de yüksektir. Buna karșılık eșit ağırlıklı fon tercihinde bulunan bireylerin sisteme ilișkin yatırım istekleri daha düșüktür. Bu, finansal okuryazarlık seviyesinin düșüklüğü ile açıklanabileceği gibi çalıșmamızda ölçülmemekle birlikte bireysel emeklilik sistemine giriș türü ile de açılanabilir. Pek çok firma çalıșanlarını sisteme girmeleri yönünde maddi olarak teșvik etmekte yahut kișiler sigorta temsilcilerinin iknası sebebiyle çok da düșünmeden bireysel emekliliğe katılmaktadır. Bu tarz katılımlar herhangi bir yatırım aracı ağırlıklı fondan ziyade eșit dağılımlı fonlara yönelmeye sebep olabilir.

Risk algısına ilișkin farklılık olușturan son değișken ise kayıp miktarıdır. Üç farklı fon türünde en düșük kayıp miktarı algısı eșit dağılımlı fon türünde ölçülmüștür. Portföy teorisi ile de uyumlu bu bulgu teorik bilgiler ile uyumludur. Bu șekilde olușturulan fonlardaki kayıp miktarının tek bir yatırım aracı ile olușturulmuș fonlardan daha düșük olması beklenen bir durumdur.

Çalıșmamızın diğer yönü ise diskriminant analizi ile kișilerin çeșitli özellikleri ile tercih ettikleri fon türü arasında ilișkiler aramaktır. Bu çerçevede bağımsız değișkenler olarak yaș, eğitim seviyesi, risk alma davranıșı, duygusal zekâ, temel ve ileri finansal okuryazarlık seviyeleri alınmıștır. Özellikle yaș, eğitim seviyesi ve risk alma davranıșı ile fon türü tercihi arasında güçlü ilișkiler tespit edilmiștir. Bu bilgi bilhassa sigorta danıșmanları açısından son derece faydalıdır. Fon türü belirleme așamasında mutlak doğru- 
dan bahsedebilmek mümkün değildir. Herkes en yüksek getiriyi elde etmek ister. Ancak riskin getirinin ayrılmaz parçası olması en yüksek getiri hedefinin aynı zamanda en yüksek kayıp durumu ile yüzleșmek anlamına geleceği așikârdır. Bu sebeple herkes kișisel özelliklerinden kaynaklanan seçim kriterleri ile kendince uygun bir yatırım alternatifine yönelir. Bu noktada finansal danıșmanlık önem kazanmaktadır. Finansal danıșmanlar karșılarındaki bireylerin tercihlerini, beklentilerini ve özelliklerini anlayarak ve değerlendirerek onlara uygun alternatifler sunmalıdır. Aksi takdirde çok kıymetli tavsiyeler verilse dahi bireylerde bıraktığı intiba ve yatıııma dönüșme ihtimali düșük kalacaktır. Bu çalıșmanın en önemli bulgularından biri de bu noktada, diskriminant analizinden elde edilen fonksiyon yardımı ile ilgili özellikleri girilen bireylerin seçmesi muhtemelen en uygun fon türünün tespiti ve buradan hareketle finansal danıșmana yardımcı olacak bilgilerin ortaya çıkarılmasıdır.

Her çalıșmanın olduğu gibi bu çalıșmanın da kısıtları mevcuttur. Bu kısıtlardan en önemlisi araștırma örnekleminin zaman, maliyet kısıtları nedeniyle küçük bir gruptan olușmasıdır. Daha geniș bir veri seti ile daha genelleștirilebilir sonuçlar üretileceği așikardır.

Katılımcıların bireysel emeklilik yatırımlarına ilișkin bazı kısıtları da mevcuttur. Örneğin, bireysel emeklilik yatırımlarının çoğu yatırımcılara önerilen, sunulan ürün türlerinden olușmakta, dolayısıyla yatırımcılar bireysel emeklililik fon tercihlerinde çok aktif bir rol almayabilmektedir. Bu durumun araștırma sonuçlarını değerlendirirken göz önünde bulundurulması gerekir.

Toplumu olușturan bireylerin emeklilik yașamlarında giderlerini karșılama konusunda yetersiz kalan devlet güvencesinin bireysel emeklilik sistemleri ile desteklemesi günümüzde son derece önem kazanmaktadır. Bu derece öneme sahip bireysel emeklilik sisteminin toplumun her kesiminde kabul görmesi ve talep edilmesi ise ancak çok sayıda farklı alternatifler vasıtasıyla toplumdaki bireysel farklılıkları kapsaması sonucu sağlanabilir. Bu ise bireysel emeklilik sistemlerinin içerdiği her unsurun ayrı ayrı araștırmalara konu olması ile gerçekleșebilir. 
Gelecekteki çalıșmaların bireyler arasında farklılașma yaratmasının önemli bir belirteci olan kișilik özelliklerinin bireylerin yatırım davranıșını nasıl etkilediği üzerinde araștırma yapmaları önerilebilir.

\section{KAYNAKÇA}

Acar, F. 2002. Duygusal zekâ ve liderlik. Sosyal Bilimler Enstitüsü Dergisi. 12: 53-68.

Alıntaș, K. M. 2009. Belirlenmiș katkı esaslı emeklilik planlarında finansal eğitimin önemi: katılımcıların finansal okuryazarlığı çerçevesinde alternatif bir yatırım eğitimi modeli. ZKÜ Sosyal Bilimler Dergisi. 5 (9): 151-176.

Ameriks, J., T. Wranik, Salovey, P. 2009. Emotional intelligence and investor behavior, Research Foundation of CFA Institute Monograph. pp. 100-104.

Arano, K., C. Parker, Terry, R. 2010. Gender-based risk aversion and retirement asset allocation. Economic Inquiry. 48 (1): 147-155.

Barak, O. 2008. Davranıșsal Finans (1. Basım) Ankara: Gazi Kitabevi.

Batool, B. F. 2013. Emotional intelligence and effective leadership. Journal of Business Studies Quarterly. 4 (3): 84-94.

Bayer, P. J., B. D. Bernheim, Scholz, J. K. 1996. The effects of financial education in the workplace: evidence from a survey of employers. NBER Working Paper Series. 5655.

Camgöz, S. M., M.B. Karan, Ergeneli, A. 2011 . Relationship between the big five personality and the financial performance of fund managers. Current Topics in Management, 15: 137-152.

Clark, G.L., K. Strauss. 2008. Individual pension-related risk propensities: the effects of socio-demographic characteristics and a spousal pension entitlement on risk attitudes. Ageing and Society, 28 (6): 847-874.

Doğan, S., Ö. Demiral. 2007. Kurumların bașarısında duygusal zekanın rolü ve önemi, Yönetim ve Ekonomi. 14 (1): 209-230.

Dulebohn, J.H. 2002. An investigation of the determinants of investment risk behavior in employer-sponsored retirement plans. Journal of Management. 28 (1): 3-26.

Dvorak, T., H. Hanley. 2010. Financial literacy and the design of retirement plans. The Journal of Socio-Economics. 39: 645-652.

Ergin, D.Y., M.B. Özgürol. 2011 . Bilimsel tutum ve duygusal zekâ arasındaki ilișki. 2nd. International Conference on New Trends in Education and Their Implications, 27-29 April 201 1, Antalya-Turkey. 
Ezadinea, N., S. Fathi, Salami, S. 2011. The effect of emotional Intelligence on protfolio performance of stakeholders: empirical evidence from iran. Interdisciplinary Journal of Contemporary Research in Business, 3 (5): 679. 685.

Gibson, R., D. Michayluk, Venter, G.V. 2013. Financial risk tolerance: an analysis of unexplored factors. Financial Services Review. 22 (1): 23-50.

Grable, J. E., M. J., Roszkowski. 2007. Self-assessments of risk tolerance by women and men. Psychological Report. 100: 795-802.

Gündüz, B. 2013. Emotional intelligence, cognitive flexibility and psychological symptoms in pre-service teachers. Academic Journals, 8 (13): 10481056.

Hilgerth, M.A., J.M. Hogarth, Beverly, S.G. 2003 July. Household financial management: the connection between knowledge and behavior. Federal Reserve Bulletin. 89: 309-322.

Howard, J. A. 2012. Behavioral finance: contributions of cognitive psychology and neuroscience to decision making. Journal of Organizational Psychology. 12(2): 52-70.

Humphrey, N., A. Curran, Morris, E., Farrell, P., Woods, K. 2007. Emotional intelligence and education: a critical review. Educational Psychology. Vol. 27 (2): 235-254.

Jorfi, S. H., S. S. Jorfi, Moghadam, S. S. K. 2010. Impact of emotional intelligence on performance of employees. Postmodern Openings. 1 (4): 63-74.

Kamalian, A., N. Yaghoubi, Poori, M. 2011. Emotional intelligence and corporate entrepreneurship: an empirical study. Journal of Basic and Applied Scientific Research, 1 (6): 471-478.

Kavcar, B. 2011. Duygusal zekâ ile akademik bașarı ve bazı demografik değișkenlerin ilișkileri: bir devlet üniversitesi örneği, Doktora Tezi, Ankara Üniversitesi Sosyal Bilimler Enstitüsü İșletme Anabilim Dalı.

Kidwell, B., D. M. Hardesty, Childers, T. L. 2008. Consumer emotional intelligence: conceptualization, measurement, and the prediction of consumer decision making. Journal of Consumer Research, 35 (1): 154-166.

Köksal, A., A.E.l. Gazioğlu. 2007. Ergenlerde duygusal zekâ ile karar verme stratejileri arasındaki ilișki. Hasan Ali Yücel Eğitim Fakültesi Dergisi, 7 (1):133-146.

Law, K., C. Wong, Huang, G., Li, X. 2008. The effect of emotional intelligence on job performance and life satisfaction for the research and development scientists in china, Asia Pasific Journal of Management, 25: $51-69$. 
Lusardi, A., O. S. Mitchell. 2007a. Baby boomer retirement security: the roles of planning, financial literacy and housing wealth. Journal of Monetary Economics. 54: 205-224.

Lusardi, A., O. S. Mitchell. 2007b. Financial literacy and retirement preparedness: evidence and implications for financial education. Business Economics, 42 (1): 35-44.

Lusardi, A., O. S. Mitchell. 2008. Planning and financial literacy: how do women fare? NBER Working Paper Series. 13750.

Lusardi, A., Tufano P. 2008. Debt literacy, financial experience and overindebtedness. NBER Working Paper Series. 14808.

Mayfield, C., G. Perdue, Wooten, K. 2008. Investment management and personality type. Financial Services Review. 17: 219-236.

Millar, M., D. Devonish. 2009. Attitudes, savings choices, level of knowledge and investment preferences of employees toward pensions and retirement planning: survey evidence from barbados. Pensions. 14 (4): 299-317.

Nakip, M. 2006. Pazarlama Araștırmaları Teknikler ve (SPSS Teknikli) Uygulamalar (Genișletilmiș 2. Basım) Ankara: Seçkin Yayınları.

Nicholson, N., E. Soane, Fenton-O'Creevy, M., Willman, P. 2005. Personality and domain-specific risk taking. journal of risk research, 8(2): 157-176.

Peggs, K. 2000. Which pension?: women, risk and pension choice. The Sociological Review, 48 (3): 349-364.

Rana, H.M., J. Khan, Baig, A. A. 2014. Information searches as a mediator between income and risky decision-making behavior and influence of education on risky decision-making behavior: a study from pakistan. The Business \& Management Review. 4 (3), 81-93.

Rooii, M. C. J., A. Lusardi, Alessie, R. J. M. 2011 a. Financial literacy and retirement planning in the netherlands. Journal of Economic Psychology. 32: 593-608.

Rooii, M. C. J., A. Lusardi, Alessie, R. J. M. 2012. Financial literacy, retirement planning and household wealth. The Economic Journal. 122: 449-478.

Rooii, M.V., A. Lusardi, Alessie, R. 2011 b. Financial literacy and stock market participation. Journal of Financial Economics. 101: 449-472.

Rosete, D., J. Ciarrochi. 2005. Emotional intelligence and its relationship to workplace performance outcomes of leadership effectiveness. Leadership \& Organization Development Journal. 26 (5/6): 388-399.

Șahin, Ș., H. Rittersberger-Tılıç, Elveren, A. Y. 2010. The individual pension system in turkey: a gendered perspective. Ekonomik Yaklașım. 21 (77): 115-142. 
Salovey, P., J.D. Mayer. 1990. Emotional intelligence, Imagination, Cognition and Personality, 9: 185-211.

Schutte, N.S., J.M. Malouff, Hall, L.E., Haggerty, D.J., Cooper, J.T., Golden, C.J., Dornheim, L. 1998. Development and validation of a measure of emotional intelligence. Personality and Individual Differences. 25: 167-177.

Sjöberg, L., E. Engelberg. 2009. Attitudes to economic risk taking, sensation seeking and values of business students specializing in finance. Journal of Behavioral Finance. 10 (1): 33-

Sosic, J. J., L.E. Megerian. 1999. Understanding leader emotional intelligence and performance the role of self-other agreement on transformation leadership perceptions. Group Organization Management. 24 (3): 367-390.

Speelman, C. P., M. Clark-Murphy, Gerrans, P. 2013. Decision making clusters in retirement savings: gender differences dominate. Journal of Family and Economic Issues. 34 (3): 329-339.

Swanson, A. C., R. Braidfoot. 2013. An assessment of emotional intelligence understanding in the field of financial planning. Global Conference on Business and Finance Proceedings, 8 (2): $41-50$.

Uygur, E. 2012. Türkiye'de tasarrufların seyri ve etkileyen bazı unsurlar. Türkiye Ekonomi Kurumu Tartıșma Metni. 2012/108.

Watson, J., M. McKnaughton. 2007. Gender differences in risk aversion and expected retirement benefits, Financial Analysts Journal, 63 (4): 52-62.

Yeniçeri, T. 2005. Tüketicilerin mağaza imajı algılamaları ve sosyo-demografik özelliklerinin alıșveriș tutarları itibariyle karșılaștırılması. Iktisadi ve Idari Bilimler Dergisi. 19 (2): 373-393.

Yeșilyaprak, B. 2001. Duygusal zeka ve eğitim açısından doğurguları, Kuram ve Uygulamada Eğitim Yönetimi. 25: 139-146.

Yilmazer T., A. C. Lyons. 2010. Marriage and the allocation of assets in women's defined contribution plans. Journal of Family and Economic Issues. 31: 121-137.

Yip, J. A., S. Côté, 2012. The emotionally intelligent decision maker: emotionunderstanding ability reduces the effect of incidental anxiety on risk taking. Psychological Science. 6: 1-8. 